DANIJELA TULAK-SUBAN, Ph.D.

E-mail: danijela.tuljak@fpp.uni-lj.si

Faculty of Maritime Studies and Transport,

University of Ljubljana

Pot pomorščakov 4, 6320 Portorož, Slovenia
Traffic Engineering

Original Scientific Paper

Submitted: 12 Nov. 2018

Accepted: 29 Aug. 2019

\title{
MCDM BUNKERING OPTIMISATION IN A HUB AND SPOKE SYSTEM: THE CASE OF THE NORTH ADRIATIC PORTS
}

\begin{abstract}
Choosing an optimal bunkering port that minimises the increase in the operating costs in a hub and spoke system is a multi-criteria decision-making (MCDM) problem. Furthermore, the criteria are related to the port particularities, the environment, fuel price, and some criteria are quantitative while others are qualitative. It is therefore necessary to create a model that takes such features into consideration. Firstly, in this paper a set of the most used criteria will be defined. Then, a method to choose suitable criteria for a hub and spoke system will be proposed. Secondly, using a Fuzzy AHP, weights will be defined and used in a multi-criteria goal function. The outcome is a bunkering policy MCDM model based on the aggregation of fuel consumption and price to criteria related to port characteristics, local aspects and service particularities. All these factors must be considered by a chief engineer (superintendent) in the process of defining a sustainable bunker policy. A case study based on the North Adriatic port system demonstrates the applicability of the proposed model. In addition, the case study highlights that in hub and spoke systems with short loops, feeder ships can regulate cargo capacity and stay at a port with bunkering policy planning.
\end{abstract}

\section{KEY WORDS}

hub and spoke; bunkering problem; multi-criteria decision making; cost optimisation; fuzzy AHP; dynamic programming;

\section{INTRODUCTION}

Determining the characteristics of optimal bunkering ports and defining optimal bunkering refuelling decisions (generally related to keeping costs down to a minimum) are problems that have been widely but separately analysed. It can also be noted that researchers have paid more attention to the optimal bunkering refuelling decision problem than to which factors and characteristics influence the choice of the bunkering port. On the other hand, the majority of the proposed models are based on linear shipping organisation [112], while researchers have seldom considered hub and spoke [13] or tramp services [14, 15].

In this paper, hub and spoke service, consisting of two levels of service - the main routes between hub ports and the feeder routes between spoke ports - will be examined. Hub ports are major, deep-sea transhipment ports and spoke ports are feeder ports of a geographical region [16]. Hub and spoke service will also be compared to linear service based on fixed routes, regular services and fixed schedules where all ports have the same role. Within the hub and spoke service there is also an inflexibly organised system with a clear diversification of the roles between hub ports and spoke ports and between deep-sea line and feeder services [17].

The literature review clearly indicates that the characteristics of optimal bunkering ports and optimal bunkering policy have not been sufficiently addressed by the studies, as up to now the authors have analysed the two problems separately. Moreover, the optimal bunkering policy problem is generally analysed in the case of a linear shipping network. Furthermore, in all the aforementioned papers the assumption has been made that ships sail exactly at the optimal speed based on mathematical models, but as a consequence of wind and sea current it is impossible to guarantee that the real speed perfectly matches the optimal one. Wang and Meng in [4] observed that the predicted total cost may be different from the real total cost and the planned "optimal" speed may no longer be optimal considering the uncertainties of real speed.

Also, it can be noted that in bunkering port choices with respect to optimal bunkering (in the case of linear shipping service, hub and spoke service or other types of services), defined as cost optimisation problems generally based on the ship speed (consumption), the optimisation has been less examined by researchers. Only in two papers [18] and [19] have the criteria used to choose a bunkering port been defined and analysed. No articles combining an adequate bunker policy with a proper bunkering port selection were found, and furthermore, authors generally took into consideration only the linear shipping service model.

In this paper a method to define the optimal bunkering policy will be proposed, and it is not only focused on minimising costs, but also takes into consideration the ballast and cargo capacity of the ship with respect to the tank volume and the appropriateness of the bunkering port according to ship requirements. 


\section{METHODOLOGY AND MODEL DEFINITION}

The bunkering policy and port choice in a hub and spoke system are defined using a three-step algorithm: (1 $1^{\text {st }}$ step) ranking of the bunkering ports, $\left(2^{\text {nd }}\right.$ step) definition of the mathematical model, and $\left(3^{\text {rd }}\right.$ step) merging of results to define an optimal bunkering policy model.

\section{Step 1: Bunkering port ranking}

It is possible to find in the literature factors which affect the performances, and competitiveness of the bunkering ports only in cases of linear shipping [18, 19]. In Table 1, the key performance factors detected in the literature review are listed in order of importance (from the most important to the least significant). The proposed order of importance is from the literature review in the case of linear shipping.

The key factors listed in Table 1 are used as a starting point in the model of effectiveness evaluation of the bunkering port in a hub and spoke system. The proposed order of importance in a hub and spoke system is not necessarily correct, as the structure of the system and the port roles are different with respect to the linear shipping model. The hub and spoke model is generally used in the case of container transhipment and the key factors with regards to ranking will be adapted to this case.

A group of experts made up of experienced academics and ship owners offering hub and spoke services in the North Adriatic was formed to define a list of the proper key factors and weights that could be used to rank bunkering ports in a hub and spoke system. On the basis of the observations made by the experts, a new factor was added to those listed in Table 1, related to the cargo (containers) on board or to be loaded. The detailed structure of the model based on the graph will be defined in the next step which is based on the expert port performance evaluation taking into consideration the specific port characteristics and the general characteristics of the hub and spoke system.

The resulting number of criteria is greater than 15 , which is the limit value for the consistency check of the AHP method; therefore, the related criteria were aggregated to form a consistent hierarchy model structure
[20]. Peer comparison using the fuzzy AHP method and the Saaty nine-stage linguistic scale, between the elements of the subcriteria level and then between elements of the next level of the hierarchy, was done to compute the global weights [21].

The final result is a hierarchy between all factors and at the same time weights of the multi-criteria objective function used in the next Section are defined; the results of the AHP method are presented in Figure 1.

The consistency check of the pairwise comparison matrix is made at the subcriteria and criteria levels. The consistency ratio (CR) obtained comparing the consistency index $(\mathrm{Cl})$ of the defined matrix and the consistency index of a random matrix (RI), as defined by Saaty, was computed at each level and the values are less than 0.1; therefore, the AHP method is consistent $[21,22]$.

On the basis of the AHP method, it is possible to note that the most relevant factors with weights greater than average are: bunker price, port tariffs, bunker quality, supply wait time, safety of bunkering, bunkering risk management, port weather conditions and cargo/containers on board or to be loaded.

With respect to the most important factors for linear shipping, it can be noted that in the case of hub and spoke, experts do not consider the geographical position, port tariffs or the port bunker fuel capacity to be the most important factors but put more emphasis on the weather conditions and cargo.

\section{Step 2: Formulation of the model}

A fuzzy discrete dynamic programming model is defined in this section on graph $G=G(V, E)$, where $V$ is the set of vertices (ports of the system) and $E$ is the set of edges (paths between ports). A multi-criteria objective function is used to compute the optimal bunkering policy at the optimal port by using weights defined in the previous Section. The optimal bunkering policy of a ship is expressed using a triangular fuzzy variable.

The bunkering policy is subject to the optimisation of the transport of full and empty containers in a hub and spoke system in a graph. This problem could be described as a Vehicle Routing Problem with Pickup and Delivery (VRPPD), [23]. It is also reasonable

Table 1 - Key performance factors for linear shipping, in order of importance

\begin{tabular}{||l|l|l||}
\hline \multicolumn{1}{|c|}{ More important factors } & \multicolumn{1}{|c||}{ Quite important factors } & \multicolumn{1}{c|}{ Less important factors } \\
\hline \hline Bunker price & Supply waiting time & Experienced human resources \\
Bunker quality & Environmental restrictions effects & Port congestion condition \\
Port time & Information sharing among stakeholders & Bunkering service at night \\
Safety of bunkering & Port weather conditions & Small order bunkering service \\
Volume of containers & Port bunker suppliers & Bunkering risk management \\
Efficiency of bunker supply & Port bunkering supply regulations & Available bunkering barge \\
Geographical advantage & & \\
Port bunker fuel capacity & & \\
Port tariffs & & \\
\hline
\end{tabular}




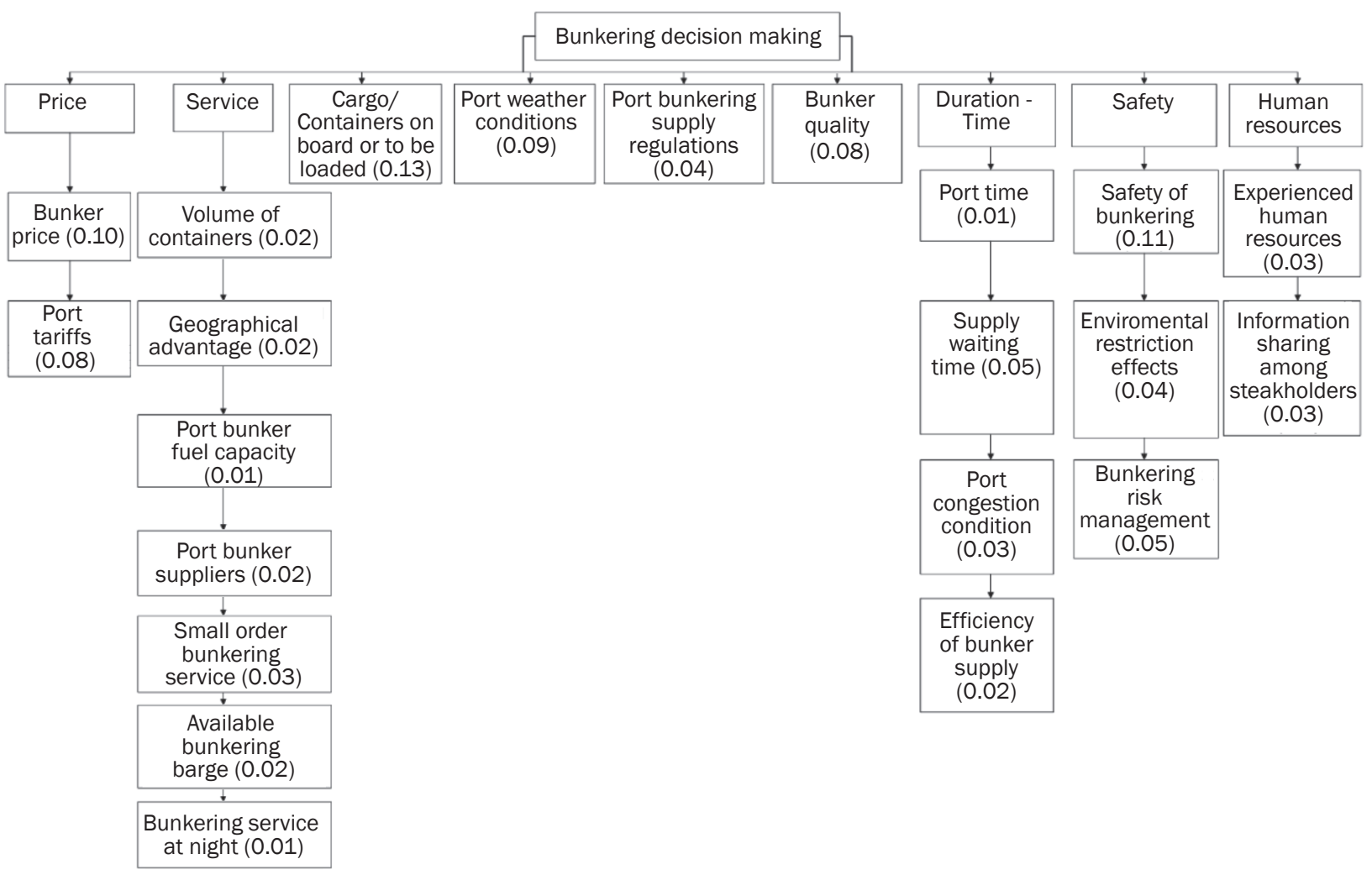

Figure 1 - Hierarchical structure and priority weight

to make the optimisation on one cycle in the graph, which is the cycle of the feeder ship that starts and ends at the hub port and visits the spoke ports.

The following notations will be used in the presented model:

$i \in \mathrm{V} \quad$-vertices (ports of the system) of the graph $G=G(V, E)$ and of the hub and spoke system; $n+1=|V|$ is the total number of the ports (bunker candidates) in the system. $i=0$ (and $i=n)$ is the hub port and $1 \leq i \leq n-1$ are the spoke ports;

$l_{i} \quad$-load cargo volume at port $i$;

$u_{i} \quad$-unload cargo volume at port $i$;

$\widetilde{b}_{i} \quad$-triangular fuzzy volume of ballast (fresh water) on board at port $i$;

$e_{i, j} \in E$-edges of graph $G=G(V, E)$ and paths of the ships, $j>i$;

$W \quad$-declared ship tank capacity;

$\widetilde{W}_{i} \quad$-available triangular fuzzy tank capacity at port $i$; the value is not constant and depends on the quantity of cargo on board and on the volume (weight) of other liquids on board, such as ballast and fresh water;

$\tilde{p}_{i} \quad$-triangular fuzzy fuel price at port $i$;

$\widetilde{Q}_{i, m}^{r} \quad$-remaining triangular fuzzy amount of fuel at port $i$ at algorithm iteration $m$, [2];

$\widetilde{Q}_{i, j}^{c} \quad$-consumed triangular fuzzy amount of fuel on the edge $e_{i, j}$ from port $i$ to port $j$, [2];

$k_{l} \quad$-weights obtained in Step 1;

$x_{i} \quad$-optimal quantity of fuel added at port $i$.
In the presented model, the following statements will be used:

A triangular fuzzy number $\widetilde{A}=\left(A^{l}, A^{m}, A^{r}\right)$ is defined by the following membership function, see [24, 25]:

$\mu_{\tilde{A}}(x)=\left\{\begin{array}{l}\frac{x-A^{l}}{A^{m}-A^{l}}, \quad A^{l}<x \leq A^{m} \\ \frac{A^{r}-x}{A^{r}-A^{m}}, \quad A^{m}<x \leq A^{r} \\ 0, \text { otherwise }\end{array}\right.$

Comparison of two triangular fuzzy numbers $\widetilde{A}=\left(A^{l}, A^{m}, A^{r}\right)$ and $\widetilde{B}=\left(B^{l}, B^{m}, B^{r}\right)$ is defined as a binary relation and $\widetilde{A}>\widetilde{B}$ iff $\mu_{P}(\widetilde{A}, \widetilde{B})>\frac{1}{2}$ see [26], where

$$
\begin{aligned}
& \mu_{P}(\widetilde{A}, \widetilde{B})=\frac{1}{2}\left(\frac{\left(A^{l}-B^{r}\right)+2\left(A^{m}-B^{m}\right)+\left(A^{r}-B^{l}\right)}{2\|(\widetilde{A}, \widetilde{B})\|}+1\right) \\
& \|\widetilde{A}, \widetilde{B}\|=\left\{\begin{array}{l}
\frac{T^{l}+2 T^{m}+T^{r}}{2}, \max \left\{A^{l}, B^{l}\right\} \geq \min \left\{A^{r}, B^{r}\right\} \\
\frac{T^{l}+2 T^{m}+T^{r}}{2}+2 T^{r}, \max \left\{A^{l}, B^{l}\right\}<\min \left\{A^{r}, B^{r}\right\}
\end{array}\right.
\end{aligned}
$$

and the next notations are used:

$$
\begin{aligned}
& T^{l}=\max \left\{A^{l}, B^{l}\right\}-\min \left\{A^{r}, B^{r}\right\}, \\
& T^{m}=\max \left\{A^{m}, B^{m}\right\}-\min \left\{A^{m}, B^{m}\right\}, \\
& T^{r}=\max \left\{A^{r}, B^{r}\right\}-\min \left\{A^{l}, B^{l}\right\} .
\end{aligned}
$$


Arithmetic operations between the triangular fuzzy numbers are based on the Zadech extension principle [27]. The membership grade of the defuzzified value obtained with the signed distance method has a greater value than those obtained with the centroid methods. Thus it makes sense to use this defuzzification method.

For the triangular fuzzy number $\widetilde{A}=\left(A^{l}, A^{m}, A^{r}\right)$ the defuzzified value obtained with the signed distance method could be defined as the signed distance of $\widetilde{A}$ to the real number $0, d \widetilde{A}, 0)=\frac{\left(A^{l}+2 A^{m}+A^{r}\right)}{4}$, [28].

The port $i$ non-dimensional evaluation, $d_{i, j}\left(\widetilde{Q}_{i, j}^{c}, \widetilde{Q}_{i, m}^{r}, \widetilde{W}_{i}\right)$, using weights and factors detected in Step 1 and the cost of the refuel needed to move from port $i$ to port $j$ without intermediate refuels (stopping ports are defined in accordance with the load and unload cargo plan) at algorithm iteration $m$ (see [29]) is defined as:

$$
\begin{aligned}
& d_{i, j}\left(\widetilde{Q}_{i, j}^{c}, \widetilde{Q}_{i, m}^{r}, \widetilde{W}_{i}\right)= \\
& \left\{\begin{array}{l}
k_{1} \frac{\left(\widetilde{Q}_{i, j}^{c}-\widetilde{Q}_{i, m}^{r}\right) \tilde{p}_{i}}{d\left(\max _{j}\left\{\left(\widetilde{Q}_{i, j}^{c}-\widetilde{Q}_{i, m}^{r}\right) \tilde{p}_{i}\right\}, 0\right)}+\sum_{l=2}^{22} k l \frac{c_{i, j}}{\max _{i, l}\left\{c_{i, j}\right\}}, 0<\widetilde{Q}_{i, j}^{c} \leq \widetilde{W}_{i} \wedge i<j \\
0, i=j \\
\infty, \text { otherwise }
\end{array}\right.
\end{aligned}
$$

$c_{0}(j)$ is the minimum weighted refuelling cost (quantity) from hub port 0 to port $j$ without intermediate refuels and considering weighted port 0 evaluation:

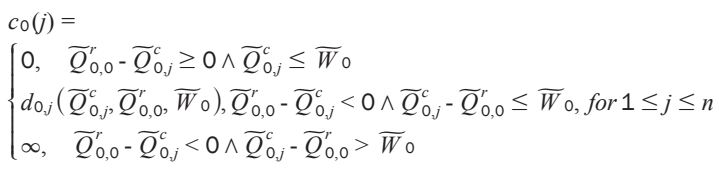

$c_{m}(j)$ is the minimum weighted refuelling cost (quantity) from port 0 to port $j$ stopping at most $m$ refuelling ports, $0 \leq m \leq n$ and taking into consideration the evaluation of stopping ports (all ports where the feeder ship stops).

The available triangular fuzzy tank capacity $\widetilde{W}_{i}$ at port $i$, as previously mentioned, is not constant and depends on the quantity of cargo on board and on the volume (weight) of other liquids on board such as ballast and fresh water and must ensure the stability of the ship.

$$
\widetilde{W}_{i}=W-l_{i}-\widetilde{b}_{i}-\widetilde{Q}_{i}^{r}+u_{i}
$$

In this paper, it is assumed that the ship loads / unloads cargo according to plan, and then refuels. Furthermore, the volume of ballast on board is a triangular fuzzy value as it could be adjusted in accordance with the fuel price and port bunkering capacities and characteristics.

The objective function, defined as the Bellman equation, is used to detect the optimal bunkering policy at the optimal port, and is defined as:

$$
\begin{gathered}
c_{m}(j)=\min _{0 \leq i<j \leq n}\left\{d_{i, j}\left(\widetilde{Q}_{i, j}^{c}, \widetilde{Q}_{i, m-1}^{r}, \widetilde{W}_{i}\right)+c_{m-1}(i),\right\}, \\
1 \leq j \leq n
\end{gathered}
$$

The algorithm computes the optimal solution when $c_{m}(j)=c_{m-1}(j)$ for $1 \leq j \leq n$ and Equation 7 reaches the equilibrium state.

\section{Step 3: Optimal bunkering policy model}

On the basis of the previous two steps, it is possible to define the ship bunkering policy in the hub and spoke model of service. It may be noted that the refuelling policy at each port is comparable to the method proposed by [2] but the amount of refuelling could be different than that of [2], as it also depends on the port suitability, cargo policy and not only on the fuel price.

The ship optimal bunker policy at the ports of the system is a sequence of fuel quantity $\left\{x_{0}, x_{1}, \ldots, x_{n}\right\}$ computed using the Bellman Equation 7 at the equilibrium state. Refuelling takes place at a proper port and the volume is defined in accordance with the fuel price, other volumes, cargo on board and an evaluation of the defined ports. The optimal bunkering policy is $x_{i}=d\left(\widetilde{Q}_{i, j}^{c}, 0\right)$ for $1 \leq i<j \leq n$ where the equilibrium value is obtained. Generally, ships are fully loaded at the hub port, and the congestion at this port is higher than in other ports, so that refuelling is done only if strictly necessary; it is therefore reasonable to assume $x_{0}=0$.

\section{CASE STUDY OF THE NORTH ADRIATIC HUB AND SPOKE SYSTEM}

This Section presents the numerical simulation between the spoke ports of the North Adriatic: the ports of Rijeka, Koper, and Venice which are part of the NAPA port system; and a hub port located in the Mediterranean Sea (see Figure 2 and [30]). The above proposed method is applied to the container ship Asiatic Moon which performs a weekly feeder service in the system. The parameters used in the case study are based on real data. The simulation was done to compare and clarify the differences between the bunkering policy found in both linear shipping and hub-and-spoke system. Also highlighted was an integrated approach which takes into consideration the bunkering price and requirement, and the properties of a given port. The compartment capacity characteristics of the 1,155 TEU container ship Asiatic Moon are presented in Table 2, [31].

Fuel consumption of a 1,155 TEU feeder ship, at an average speed of 16 knots, [32], could be evaluated on the basis of data analysis and previous research $[33,34]$, as a triangular fuzzy value $(37,40,43)$ tons/ day. 
Table 2 - Asiatic Moon feeder ship characteristics

\begin{tabular}{||l|c|c||}
\hline \multicolumn{1}{|c|}{ Compartment capacity } & Volume 100\% full [m $\left.{ }^{3}\right]$ & Weight 100\% full [tons] \\
\hline \hline Diesel oil capacity & 91.25 & 82.125 \\
\hline Freshwater capacity & 116.64 & 116.64 \\
\hline Fuel oil capacity & $1,258.55$ & $1,233.38$ \\
\hline Hydraulic oil capacity & 14.24 & 111.033 \\
\hline Lube oil capacity & 123.37 & \\
\hline Other capacity & 78.18 & $4,735.92$ \\
\hline Tank ballast capacity & $4,620.41$ & \\
\hline
\end{tabular}

Table 3 - Fuzzy fuel consumption (tons) on the connections in the graph

\begin{tabular}{||c|c|c|c|c|c||}
\hline & Node 0 & Node 1 & Node 2 & Node 3 & Node 4 \\
\hline \hline Node 0 & $(0,0,0)$ & $(67.45,72.92,78.39)$ & $(80.65,87.19,93.73)$ & $(86.62,93.65,100.67)$ & $(154.07,166.56,179.05)$ \\
\hline Node 1 & - & $(0,0,0)$ & $(13.2,14.27,15.34)$ & $(19.17,20.73,22.28)$ & $(86.62,93.65,100.67)$ \\
\hline Node 2 & - & - & $(0,0,0)$ & $(5.97,6.46,6.94)$ & $(73.42,79.38,85.33)$ \\
\hline Node 3 & - & - & - & $(0,0,0)$ & $(67.45,72.92,78.39)$ \\
\hline Node 4 & - & - & - & - & $(0,0,0)$ \\
\hline
\end{tabular}

In Table 3 the values of $\widetilde{Q}_{i, j}^{c}$, fuzzy fuel consumption (in tons) of the feeder ship are presented between the nodes of the cruise itinerary presented as a loop of the hub and spoke graph. The graph is defined in accordance with the feeder cargo plan, where the solid lines are parts of the ship itinerary and the dashed lines are added connections needed for the model (see Figure 2).

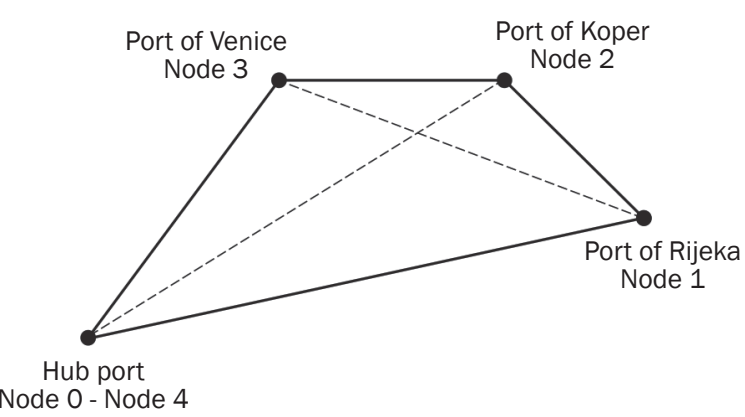

Figure 2 - A loop of the hub and spoke graph

Using the hierarchy of the appropriate factors to evaluate the bunkering port efficiency as defined in the first step of the model, the suitability of the ports of the North Adriatic hub and spoke system is evaluated. The results are computed using a five-stage rating scale ( 5 is poor, 4 is fair, 3 is good, 2 is very good and 1 is excellent). The initial fuel oil tank capacity is $\widetilde{W}_{0}=(1,245 ; 1,258 ; 1,259)$ and the initial remaining fuzzy amount of fuel at the hub port is $\widetilde{Q}_{0,0}^{r}=(70,80,90)$ tons, which makes it possible to reach at most Node 1 of the itinerary. Three simulations of port evaluations are presented: a) all spoke ports are equally evaluated except the hub port (worst evaluation); b) Node 1 has a better evaluation than the other nodes; and c) Node 1 has the worst evaluation of the other nodes and the fuel price is different at the ports of the systems. Variations are made of estimates only between the factors that are most relevant in the AHP method in the case of hub and spoke. The triangular fuzzy price of fuel is $\tilde{p}_{i}=(335,340,345) \$ /$ tons (IFO 380) and it is the same at all ports as the ports are very close. The port tariffs applied to bunkering are different as the ports are not in the same countries.

Simulation a) All ports are equally evaluated except the hub port (worst evaluation)

In the hub port, the frequency of operations, bunkering waiting time and the amount of cargo on board are greater than at the spoke ports. In this case, all the spoke nodes are equally evaluated except the hub port and the model is the same as those based on the fuel price and consumption. Ports evaluations and values of the most relevant factors of the AHP model are presented in Figure 3.

Using Equations 1-5 and the triangular fuzzy number arithmetic, the initial values $c_{0}(j)$ are: $c_{0}(0)=0, c_{0}(1)=0$, $c_{0}(2)=0.70, c_{0}(3)=0.70$, and $c_{0}(4)=0.79$.

On the basis of Equation 7 the values of $c_{1}(0)=0$, $c_{1}(1)=0, \quad c_{1}(2)=0.52, \quad c_{1}(3)=0.52, \quad c_{1}(4)=0.61$ and of $c_{2}(0)=0, c_{2}(1)=0, c_{2}(2)=0.52, c_{2}(3)=0.52$, and $c_{2}(4)=0.61$ are computed.

In the second iteration $c_{1}(j)=c_{2}(j)$ for all $j$, consequently the values of $c_{2}(j)$ define the optimal bunkering policy: $x_{0}=0, x_{1}=d\left(\widetilde{Q}_{1,4}^{c}, 0\right)=86.56$ tons, $x_{2}=0$ and $x_{3}=0, x_{4}=0$.

In this case the objective function, see Equation 7, defines a bunkering policy based on fuel consumption, price (tariffs) and cargo on board, since the fuel price is the same in all ports of the system, but the port tariffs are different and the spoke ports have comparable bunkering performances evaluation.

Therefore, it is reasonable to maximally refuel at the first port where necessary and it is not convenient to repeat refuelling more times if this is not dictated 


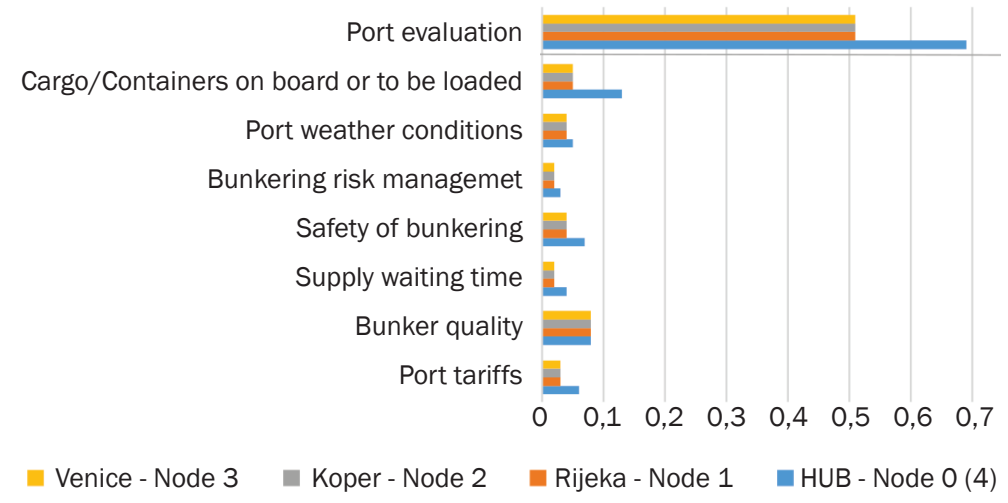

Figure 3 - The most relevant factors of AHP values when spoke ports are equally evaluated

by the amount of cargo on board. The obtained results are comparable with the results obtained in the case of linear shipping organisation models [1-12], based on fuel consumption.

\section{Simulation b) Node 1 has better evaluation than the other nodes}

The port of Rijeka has a better evaluation than the Port Koper (or of all the other ports) at the same fuel prices resulting in no changes to the optimal bunkering policy.

As in the previous case, changes are made just on the criteria that have a greater weight than the average in the AHP evaluation, see Figure 4.

Using Equations 1-5 and the triangular fuzzy number arithmetic, the initial values $c_{0}(j)$ are: $c_{0}(0)=0, c_{0}(1)=0$, $c_{0}(2)=0.70, c_{0}(3)=0.70$, and $c_{0}(4)=0.79$.

On the basis of Equation 7 the values of $c_{1}(0)=0$, $c_{1}(1)=0, \quad c_{1}(2)=0.52, \quad c_{1}(3)=0.52, \quad c_{1}(4)=0.61 \quad$ and of $c_{2}(0)=0, c_{2}(1)=0, c_{2}(2)=0.52, \quad c_{2}(3)=0.52$, and $c_{2}(4)=0.61$ are computed.

In the second iteration $c_{1}(j)=c_{2}(j)$ for all $j$, consequently the values of $c_{2}(j)$ define the optimal bunkering policy: $x_{0}=0, x_{1}=d\left(\widetilde{Q}_{1,4}^{c}, 0\right)=86.56$ tons, $x_{2}=0$ and $x_{3}=0, x_{4}=0$.

In this case the fuel price is the same at all ports of the system (but port tariffs are different) and the port evaluations are different so the obtained result takes into account both models: the fuel consumption model and the bunkering ports properties evaluation model. However, since the evaluation of the hub port is worse than the evaluation of other ports, the most proper decision is to refuel at the port of Rijeka since the port tariffs are lower than in the other ports and the AHP evaluation of the port is better than that of the other ports.

Simulation c) Node 1 has the worst evaluation of all the other nodes.

In this case the port of Rijeka has the worst evaluation, the port tariffs are different and the fuel price is the same in all ports of the system, as before (see Figure 5). This simulation is made to highlight how port evaluation could change the refuelling policy obtained in the previous simulations. Using Equations 1-5 and the triangular fuzzy number arithmetic, the initial values $c_{0}(j)$ are: $c_{0}(0)=0, c_{0}(1)=0, c_{0}(2)=0.60, c_{0}(3)=0.60$, and $c_{0}(4)=0.69$.

On the basis of Equation 7 the values of $c_{1}(0)=0$, $c_{1}(1)=0, \quad c_{1}(2)=0.60, \quad c_{1}(3)=0.60, \quad c_{1}(4)=0.69$ and of $c_{2}(0)=0, \quad c_{2}(1)=0, \quad c_{2}(2)=0.60, \quad c_{2}(3)=0.60$, and $c_{2}(4)=0.69$ are computed.

In the second iteration $c_{1}(j)=c_{2}(j)$ for all $j$, consequently the values of $c_{2}(j)$ define the optimal bunkering policy: $x_{0}=d\left(\widetilde{Q}_{0,4}^{c}, 0\right)=86.56$ tons, $x_{1}=0, x_{2}=0$ and $x_{3}=0, x_{4}=0$.

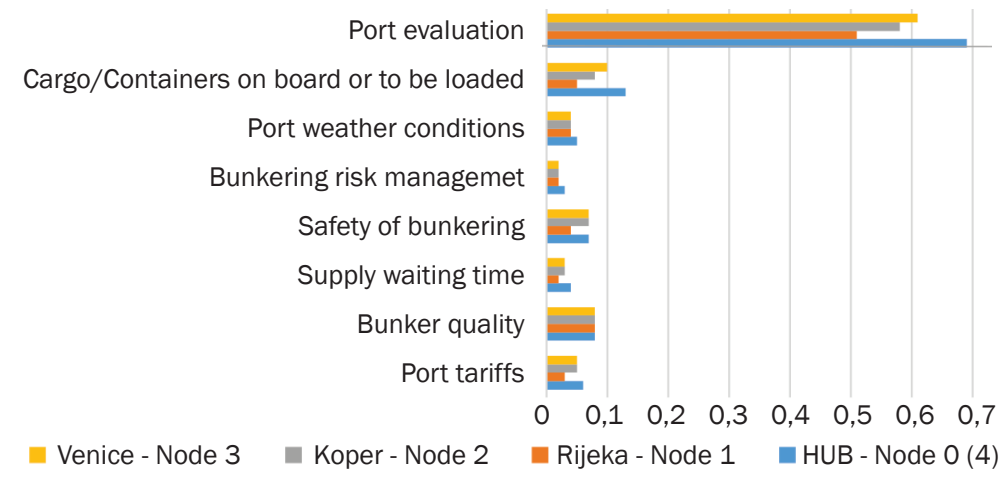

Figure 4 - The most relevant factors of AHP values when spoke ports are differently evaluated 


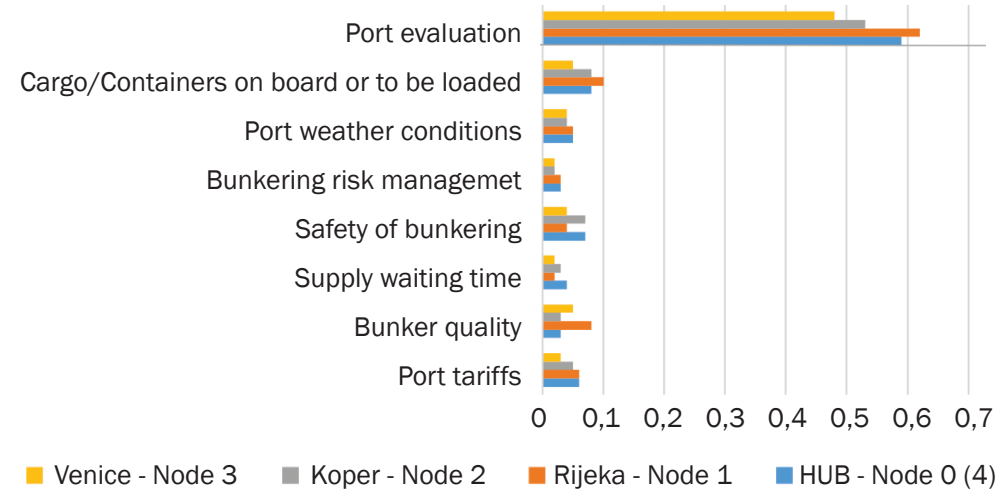

Figure 5 - The most relevant factors of AHP values when hub port is not the worst

In this case, also the fuel price and port characteristics are considered at the same time. The refuelling is done at the hub port and the added quantity is the same as in the previous simulations. The choice of a different port is due to the change in the assessment of the ports on the itinerary, which highlights the importance of including the evaluation of the port bunkering performances in the overall selection process of the optimal bunkering port and optimal refuelling policy.

\section{CONCLUSION}

The hub and spoke definition of optimal bunkering policy with respect to the case of linear shipping bunkering policy is correlated more to the port properties, as the required accuracy of itinerary planning for the feeder ship is greater.

The case study, comparing feeder ship fuel capacity (see Table 2) and the average fuel consumption on small spoke loops (see Table 3), reveals that the feeder ship does not necessarily need to refuel at each round trip.

From Table 2 it is possible to note that the declared fuel oil tank capacity for the considered feeder ship is $1,233.38$ tons, which exceeds by far the consumption during a cycle that could be estimated at 300 tons of fuel in case of standard weather, service and port conditions.

It is therefore, possible to plan the choice of refuelling port and at the same time consider the bunkering tariffs, in order to achieve not only the optimisation of fuel price but also the suitability of the port and cargo requirements. In this way, all sustainability pillars could be improved upon: the economic, environmental and social ones. By taking into consideration the structural and organisational characteristics of the ports in addition to the economic aspect, one reduces the possibility of human error and accidents that can result in pollution. On the other hand, the experts involved in the AHP evaluation consider cargo an extremely relevant factor, so that a feeder ship can adequately refuel, to maximally exploit the ship cargo capacity.

This may indicate that feeder ships, on small spoke loops, tend to regulate the loading capacity and the stay duration in a port also by exploiting the capacities of the fuel tank, as demonstrated with simulations b) and c).

The case study reveals that it is rational to add the minimum required amount of fuel at the hub port, in a hub and spoke system with short cycles, due to the large amount of cargo on board. If, however, the other spoke ports have a worse evaluation than the hub port and the same fuel tariff, it seems optimal to add all the necessary fuel at this port (simulation c)). Otherwise, if the spoke ports have a better evaluation than the hub port, it seems reasonable to add all the necessary fuel at the spoke port with the best evaluation (simulation b)).

Basing the bunkering policy only on fuel price, as in linear shipping, does not allow one to consider the possibility of maximal loading or the adequacy of the ports (simulation a)). This can cause delays and increase costs.

This shows that the proposed MCDM model, which simultaneously considers the price of fuel, the cargo on board and the port characteristics, defines the bunkering policy differently from the one based only on fuel prices. The bunkering policy obtained is more correlated to the availability and limitations of ports that could influence the quantity of the cargo on board. In addition, the case study simulations highlight that in the North Adriatic hub and spoke system, feeder ships regulate the cargo capacity and the stay at a port by using bunkering planning. This is an example of a hub and spoke system with short loops; the results obtained can also be applied to other systems with the same characteristics.

\section{Dr. DANIJELA TULJAK-SUBAN}

E-mail: danijela.tuljak@fpp.uni-lj.si

Fakulteta za pomorstvo in promet, Univerza v Ljubljani

Pot pomorščakov 4, 6320 Portorož, Slovenija 


\section{VEČKRITERIJSKA OPTIMIZACIJA VKRCANJA GORIVA V SISTEMU "HUB AND SPOKE“: PRIMER PRISTANIŠČ SEVERNEGA JADRANA}

\section{POVZETEK}

Izbira optimalnega pristanišča za vkrcanje goriva, ki zmanjša stroške obratovanja $v$ "Hub and Spoke" sistemu, je večkriterijska odločitev. Razen nje, so v članku uporabljeni kriteriji kvantitativne in kvalitativne narave, vezani na posebnosti pristanišč, okolja ter ceno goriva. Uporabljeni model izbire, mora upoštevati vse naštete značilnosti. Najprej določimo nabor najbolj uporabljenih kriterijev, nakar se določi metoda za izbiro primernih kriterijev v primeru "Hub and Spoke" sistema. S pomočjo Fuzzy AHP metode se nato določijo uteži večkriterijske namenske funkcije. Rezultat je model večkriterijske optimizacije vkrcanja goriva, ki hkrati upošteva tako porabo in ceno goriva kakor tudi kriterije, ki določajo značilnosti pristanišča, lokalne vidike in posebnosti storitev. Pri določanju trajnostne politike krcanja goriva morajo biti vsi ti dejavniki upoštevani. Primer, pristanišč v sistemu severnega Jadrana, kaže uporabnost predlaganega modela. Posebej pride do izraza, da se $v$ takih sistemih, kjer so razdalje med pristanišči majhne, za načrtovanje količine vkrcanega tovora in trajanje postanka $v$ pristanišču lahko uporablja tudi količina vkrcanega goriva.

\section{KLJUČNE BESEDE}

Hub and Spoke; problem vkrcanja goriva; večkriterijsko odločanje; optimizacija stroškov; Fuzzy AHP; dinamično programiranje;

\section{REFERENCES}

[1] Wang Y, Meng Q, Kuang H. Jointly optimizing ship sailing speed and bunker purchase in liner shipping with distribution-free stochastic bunker prices. Transp Res Part C Emerg Technol. 2018;89: 35-52.

[2] Zhen L, Wang S, Zhuge D. Dynamic programming for optimal ship refueling decision. Transportation Research Part E. 2017;100: 63-74.

[3] Aydin N, Lee H, Mansouri SA. Speed optimization and bunkering in liner shipping in the presence of uncertain service times and time windows at ports. European Journal of Operational Research. 2017;259(1): 143-54.

[4] Wang S, Meng Q. Discrete Optimization: Robust bunker management for liner shipping networks. European Journal of Operational Research. 2015;243: 789-97.

[5] Sheng X, Chew EP, Lee LH. (s,S) policy model for liner shipping refueling and sailing speed optimization problem. Transportation Research Part E. 2015;76: 76-92.

[6] Pedrielli G, Lee LH, Ng SH. Optimal bunkering contract in a buyer-seller supply chain under price and consumption uncertainty. Transportation Research Part E. 2015;77: 77-94.

[7] Ghosh S, Lee LH, Ng SH. Bunkering decisions for a shipping liner in an uncertain environment with service contract. European Journal of Operational Research. 2015;244(3): 792-802.

[8] Yanyan T, Jianfeng M. Towards Green Shipping with Integrated Bunkering and Cruising Policy. IFAC Proceedings Volumes. 2014;47: 314-9.

[9] Vilhelmsen C, Lusby R, Larsen J. Tramp ship routing and scheduling with integrated bunker optimization. EURO Journal of Transportation \& Logistics. 2014;3(2): 143.

[10] Sheng XM, Lee LH, Chew EP. Dynamic determination of vessel speed and selection of bunkering ports for liner shipping under stochastic environment. OR Spectrum. 2014;36(2): 455-80.

[11] Plum CEM, Jensen PN, Pisinger D. Bunker purchasing with contracts. Maritime Economics \& Logistics. 2014;16(4): 418.

[12] Kim HJ. A Lagrangian heuristic for determining the speed and bunkering port of a ship. J Oper Res Soc. 2014;65(5): 747-54.

[13] Zhen L, Shen T, Wang S, Yu S. Models on ship scheduling in transshipment hubs with considering bunker cost. International Journal of Production Economics. 2016;173: 111-21.

[14] Meng Q, Wang S, Lee C-Y. A tailored branch-and-price approach for a joint tramp ship routing and bunkering problem. Transportation Research Part B: Methodological. 2015;72: 1-19.

[15] Wang S, Meng Q, Liu Z. Bunker consumption optimization methods in shipping: A critical review and extensions. Transportation Research Part E: Logistics and Transportation Review. 2013;53: 49-62.

[16] Christiansen M, Fagerholt K, Nygreen B, Ronen D. Chapter 4 Maritime Transportation. Handbooks in Operations Research and Management Science. Vol. 14; 2007. p.189-284. Available from: doi:10.1016/S09270507(06)14004-9

[17] Meng Q, Wang T, Wang S. Short-term liner ship fleet planning with container transshipment and uncertain container shipment demand. European Journal of Operational Research. 2012;223(1): 96-105.

[18] Acosta M, Coronado D, Del Mar Cerban M. Bunkering competition and competitiveness at the ports of the Gibraltar Strait. Journal of Transport Geography. 2011;19: 911-6.

[19] Wang Y, Yeo G-T, Ng AKY. Choosing optimal bunkering ports for liner shipping companies: A hybrid Fuzzy-Delphi-TOPSIS approach. Transport Policy. 2014;35: 358-65.

[20] Franek J, Kresta A. Judgment Scales and Consistency Measure in AHP. Procedia Economics and Finance. 2014;12: 164-73.

[21] Saaty RW. The analytic hierarchy process-what it is and how it is used. Mathematical Modelling. 1987;9(3-5): 161-76.

[22] Saaty TL. The analytic hierarchy process: planning, priority setting, resource allocation. New York [u.a.]: McGraw-Hill; 1980.

[23] Tuljak-Suban D, Twrdy E. Decision support for optimal repositioning of containers in a feeder system. Promet - Traffic - Traffico. 2008;20(2): 71-7.

[24] Zadeh LA. Fuzzy sets. Information and Control. 1965;8(3): 338-53.

[25] Chou CC. The canonical representation of multiplication operation on triangular fuzzy numbers. Computers \& 
Mathematics with Applications. 2003;45(10): 1601-10.

[26] Wang Y-J. Ranking triangle and trapezoidal fuzzy numbers based on the relative preference relation. Applied Mathematical Modelling. 2015;39(2): 586-99.

[27] de Barros LC, Bassanezi RC, Lodwick WA. A First Course in Fuzzy Logic, Fuzzy Dynamical Systems, and Biomathematics: Theory and Applications. Springer Berlin Heidelberg; 2016.

[28] Tuljak Suban D, Bogataj M. An Optimal Ordering Cycle at Interactions of Fuzzy Parameters and High Disposal Fees of Food or Drug Supply Systems. IFAC-PapersOnLine. 2015;48(3): 2374-9. Available from: doi:10.1016/j.ifacol.2015.06.443

[29] Ginevičius R. Normalization of quantities of various dimensions. Journal of Business Economics and Management. 2008;9(1): 79-86.

[30] NAPA. North Adriatic Ports Association. 2013.
[31] Tracking V. Ship and Container Tracking. Available from: http://www.vesseltracking.net/ship/asiatic-moon9366421

[32] Dell'Acqua G, Wegman F. Transport Infrastructure and Systems. Proceedings of the AllT International Congress on Transport Infrastructure and Systems, 10-12 April 2017, Rome, Italy. CRC Press; 2017.

[33] Notteboom TE, Vernimmen B. The effect of high fuel costs on liner service configuration in container shipping. Journal of Transport Geography. 2009;17(5): 325-37.

[34] Notteboom T, Cariou P, editors. Fuel surcharge practices of container shipping lines: Is it about cost recovery or revenue making: Proceedings of the 2009 International Association of Maritime Economists (IAME) Conference, 24-26 June 2009, Copenhagen, Denmark. ITMMA; 2009. 